\title{
Prediction of gas holdup in the three-phase fluidized bed: air/Newtonian and non-Newtonian liquid systems
}

\author{
Sivakumar V. $^{1^{*}}$, Senthilkumar $\mathrm{K}_{0^{2}}$, Kannadasan $\mathrm{T}^{3}$ \\ ${ }^{1}$ Kongu Engineering College, Department of Food Technology, Perundurai, Erode-638052, India \\ ${ }^{2}$ Erode Sengunthar Engineering College, Department of Chemical Engineering, Thudupathi, Erode-638057, India \\ ${ }^{3}$ Anna University, Coimbatore, Director of Research, Coimbatore, India \\ *Correspondence author: drvsivakumar@yahoo.com
}

\begin{abstract}
The application of the three-phase fluidization technology in wastewater treatment and other biochemical processes has been regularly addressed in the past decades. For the design and development of the threephase fluidized bed reactors, knowledge of the hydrodynamic parameter such as gas holdup is essential and hence in this paper an attempt has been made to study the effect of fundamental and operating variables on gas holdup. On the basis of the experimental results, a unified correlation has been developed to predict gas holdup in the fluidized bed using the Newtonian and the non-Newtonian liquids. The experimental results showed good agreement with those predicted according to the developed correlation.
\end{abstract}

Keywords: Gas holdup, fluidized beds, non-Newtonian liquids, multiphase reactors, hydrodynamics.

\section{INTRODUCTION}

During the recent years the three-phase fluidized beds have emerged as one of the most promising devices for the applications in many industrial processes such as coal liquefaction, catalytic hydrogenation and desulphurization of petrochemicals, Fischer-Tropsch synthesis, biochemical fermentation and biological waste water treatment processes, polymerization processes, etc. The three-phase fluidized bed is preferred in many industries because of simple design and construction, high mass transfer rates as a result of good mixing ${ }^{1-5}$. Now it has gained importance in biotechnology also, where bacteria or enzymes are entrapped within porous particles or immobilized on the surface of the inert solids ${ }^{4-7}$. The successful scale up, design and operation of the fluidized beds mainly depend on the accurate prediction of the behavior and features of the system such as gas holdup. Over the years, many significant contributions have been made by investigators towards gas holdup in fluidized beds ${ }^{\mathbf{8}}{ }^{\mathbf{1 6}}$. Mostly Newtonian liquids were used to develop the correlations for the prediction of gas holdup ${ }^{11-13,17}$. The use of nonNewtonian liquids for the prediction of gas holdup has been done only on a limited scale ${ }^{\mathbf{1 7 - 2 0}}$. Since most of the industrial effluents behave as power law fluids, there is a vital need to obtain data with a wide range of variables using non-Newtonian liquids and to develop a generalized correlation to represent the data ${ }^{4,5,15,18,19,21}$. Since many biochemical reaction fluids behave as power law nonNewtonian liquids, an attempt has been made to study the effect of fundamental and operating variables on gas holdup, and also to develop a unified correlation for the estimation of gas holdup using the Newtonian and the non-Newtonian liquids.

\section{EXPERIMENTAL SETUP AND PROCEDURE}

All experiments were carried out in a Perspex column (0.15 $\mathrm{m}$ inner diameter and $1.8 \mathrm{~m}$ height) as shown in Fig. 1 . The details of the experimental apparatus can be found elsewhere ${ }^{3,22}$. The details of the properties of the solids and fluids used in the present study are given in Table 1.
Water, different concentrations of glycerol (lab grade and commercial grade), butyric acid and Mono Ethanol Amine (MEA) were Newtonian liquid systems and different concentrations of Carboxy Methyl Cellulose (CMC), were the non-Newtonian liquids and 12 different particles were used. The experimental column had a provision to feed the gas and liquid at the bottom of the column. Compressed air was fed into the bottom of the column through a pressure regulating valve. A gas distributor was provided at the bottom of the fluidized column, whereas, a gasliquid separator was provided at the top of the fluidized column. The gas-liquid distributor is designed in such a way that uniformly distributed gas and liquid mixtures entered the fluidized column. The distributor section was made up of conical Plexiglas of $0.3 \mathrm{~m}$ in height, had a divergence angle of $4.5^{\circ}$. The higher cross section end was fitted to a testing section, with a perforated plate made of perspex sheet of $0.001 \mathrm{~m}$ thick, $0.15 \mathrm{~m}$ diameter having the opening area of approximately $20 \%$ of the column area in between covered with 20 mesh stainless steel screen at the top. $0.0008 \mathrm{~m}$ diameter holes in triangular pitch were made in 15 circles of nearly $0.005 \mathrm{~m}$ gap from the centre. After attaining a steady state condition, air and liquid flow rates were suddenly stopped by closing both the valves simultaneously and gas holdup was measured ${ }^{14}$, 19. The experimental results were randomly checked and it was found that the reproducibility of the errors was within $\pm 2 \%$. The equivalent volume diameter of non spherical particles has been calculated by using the following formula:

$\frac{\pi d_{p}{ }^{3}}{6}=$ Volume of one non-spherical particle

Where $d_{p}$ spherical volume equivalent diameter, which is the diameter of a sphere whose volume is the same as that of the solid volume of non spherical particle. Shear stress and shear rate were calculated using Brookfield Rheometer (model LVDV- II+). By plotting shear stress versus shear rate, the flow consistency index $(\mathrm{k})$ and fluid behaviour index (n) were calculated. 


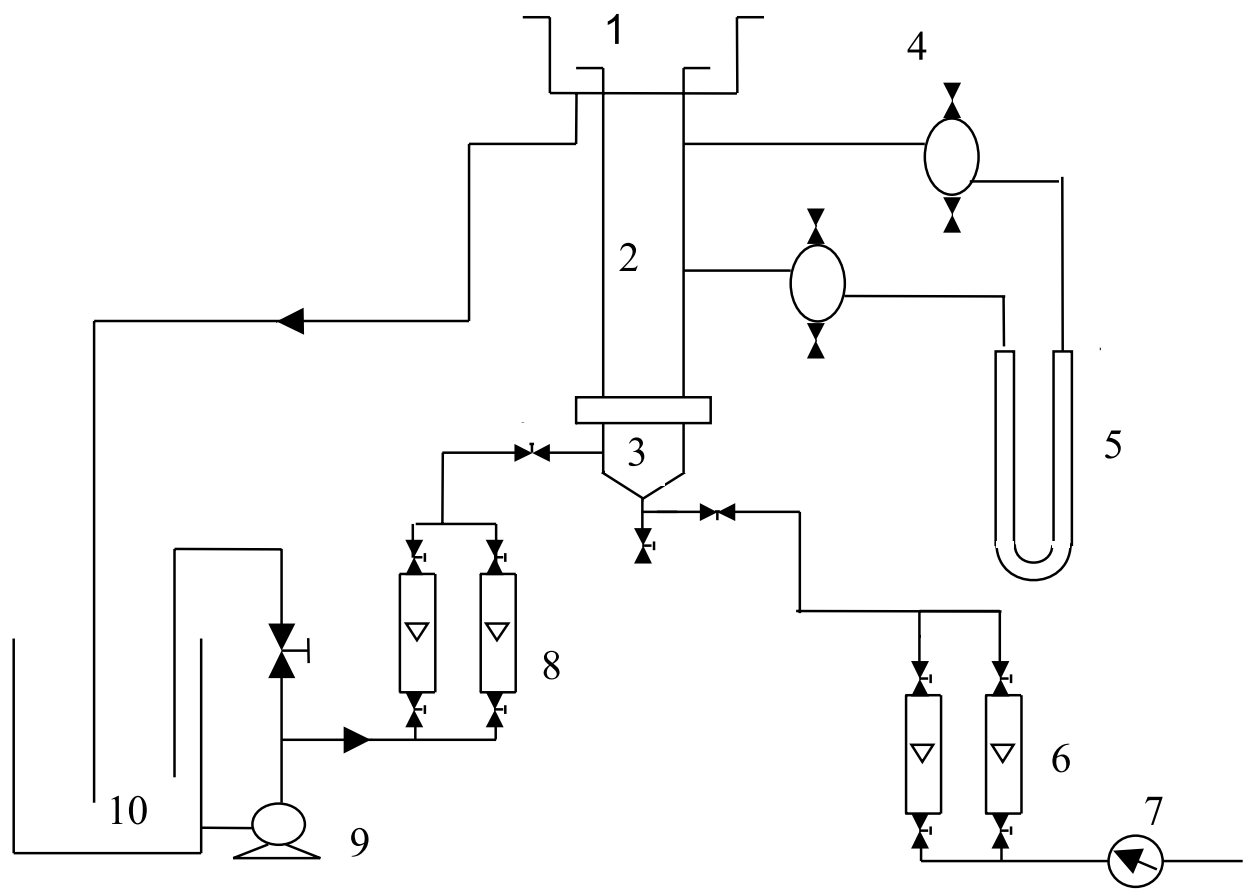

1. Disengagement section 2. Testing section 3.Claming section 4.Gas-liquid separators 5. Manometers 6.Gas rotameters 7.Pressure regulating valve 8 .Liquid rotameters 9 . Circulating pump 10. Liquid storage tank

Figure 1. Schematic of the experimental setup

Table 1. The details of the particles and liquid system used in this work

\begin{tabular}{|c|c|c|c|c|c|}
\hline \multicolumn{2}{|c|}{ Bed Characteristics } & \multirow{2}{*}{$\frac{\mathrm{d}_{\mathrm{p}} / \mathrm{mm}}{1}$} & \multirow{2}{*}{$\frac{\rho_{\mathrm{s}} / \mathrm{kg} \mathrm{m}^{-3}}{2480}$} & \multirow{2}{*}{$\begin{array}{ll}\phi_{\mathrm{s}} & \\
& 1\end{array}$} & \multirow{2}{*}{$\frac{\mathrm{D} / \mathrm{mm}}{150}$} \\
\hline Particle 1 & Spheres & & & & \\
\hline Particle 2 & Spheres & 2 & 2480 & 1 & 150 \\
\hline Particle 3 & Spheres & 4 & 2480 & 1 & 150 \\
\hline Particle 4 & Spheres & 5.5 & 2480 & 1 & 150 \\
\hline Particle 5 & Spheres & 7.2 & 2480 & 1 & 150 \\
\hline Particle 6 & Spheres & 10.36 & 2114 & 1 & 150 \\
\hline Particle 7 & Berl Saddles & 4.8 & 2050 & 0.33 & 150 \\
\hline Particle 8 & Berl saddles & 6.58 & 2213 & 0.33 & 150 \\
\hline Particle 9 & Berl saddles & 11.5 & 2456 & 0.33 & 150 \\
\hline Particle 10 & Raschig Rings & 5.1 & 2480 & 0.58 & 150 \\
\hline Particle 11 & Raschig Rings & 3.51 & 2173 & 0.58 & 150 \\
\hline Particle 12 & Raschig Rings Rings & 13.66 & 2083 & 0.58 & 150 \\
\hline \multicolumn{2}{|c|}{ Properties of Fluids } & $\rho_{l} / \mathrm{kg} \mathrm{m}^{-3}$ & \multicolumn{2}{|l|}{$\mu_{1} / \mathrm{kg} \mathrm{m}^{-1} \mathrm{~s}^{-1}$} & \\
\hline & & & $\mathrm{K} / \mathrm{kg} \mathrm{m}^{-1} \mathrm{~s}^{\mathrm{n}-2}$ & $\mathrm{n}$ & $\sigma_{\mathrm{l}} / \mathrm{Nm}^{-1}$ \\
\hline System 1 & Water & 1000 & 0.00085 & 1 & 0.072 \\
\hline System 2 & $\begin{array}{l}\varphi=20 \% \text { glycerol } \\
\text { (commercial grade) }\end{array}$ & 1010 & 0.002 & 1 & 0.069 \\
\hline System 3 & $\begin{array}{l}\varphi=60 \% \text { glycerol } \\
\text { (commercial grade) }\end{array}$ & 1020 & 0.006 & 1 & 0.069 \\
\hline System 4 & $\begin{array}{l}\varphi=90 \% \text { glycerol } \\
\text { (commercial grade) }\end{array}$ & 1040 & 0.01 & 1 & 0.068 \\
\hline System 5 & $\varphi=65 \%$ glycerol (lab grade) & 1158 & 0.019 & 1 & 0.069 \\
\hline System 6 & $\begin{array}{l}=85 \% \text { glycerol } \\
\text { (lab grade) }\end{array}$ & 1185 & 0.032 & 1 & 0.068 \\
\hline System 7 & MEA & 1050 & 0.015 & 1 & 0.045 \\
\hline System 8 & Butyric acid & 1010 & 0.001 & 1 & 0.039 \\
\hline System 9 & $\mathrm{w}=0.1 \% \mathrm{CMC}$ & 1020 & 0.0084 & 0.92 & 0.072 \\
\hline System 10 & $w=0.5 \% \mathrm{CMC}$ & 1020 & 0.0184 & 0.88 & 0.071 \\
\hline System 11 & $w=1 \% \mathrm{CMC}$ & 1020 & 0.0550 & 0.86 & 0.069 \\
\hline
\end{tabular}

\section{RESULTS AND DISCUSSION}

The experimentally measured gas holdup values obtained in the present study have been analyzed for their dependency on the fundamental and operating variables such as superficial gas and liquid velocities, size and shape of the solid particles, physical and rheological properties of the fluids. From the experimental results, it was observed that both the superficial gas and liquid velocities 


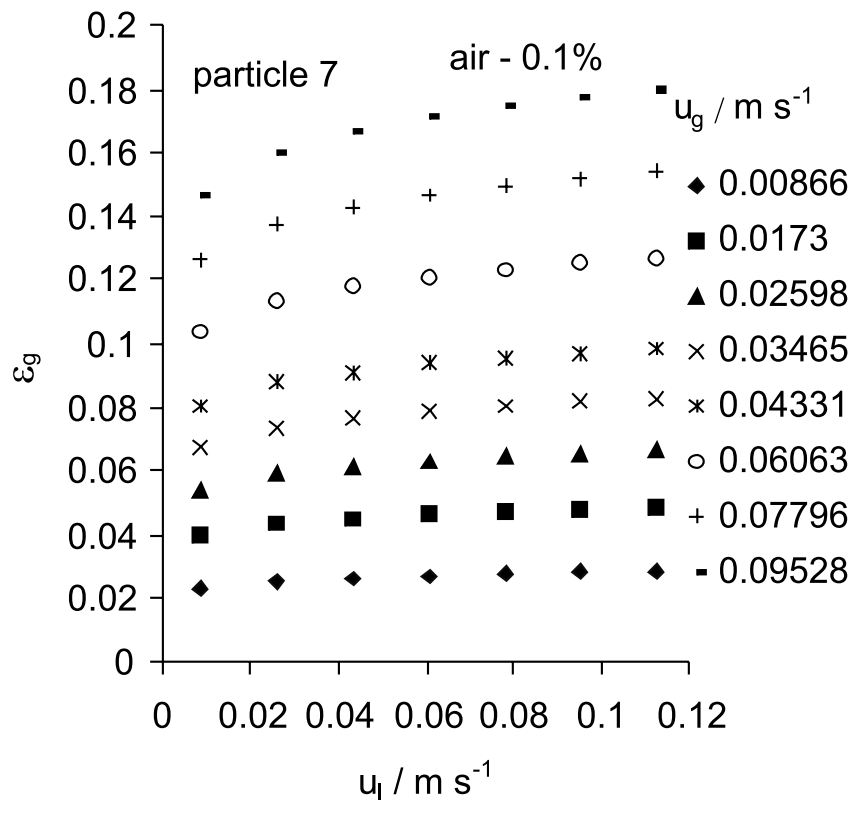

Figure 2. The effect of liquid and gas velocities on gas holdup

had a significant effect on gas holdup. Fig. 2 shows the variation in the gas holdup with respect to superficial liquid and gas velocities for the particle size $\left(d_{p}\right)$ of 4.8 $\mathrm{mm}$ for air-0.1\% CMC system. The gas holdup increased with an increase in gas velocity for a constant liquid flow rate. The same trend was observed in previous studies $\mathbf{4 , 6 , 2 3}$. However, the increase of gas holdup with an increase of liquid velocity is not significant at low superficial gas velocities where as at higher superficial gas velocities gas holdup was increased slightly. This trend coincides with the results published by the previous authors ${ }^{18,19}$. The effect of particle size on gas holdup is shown in Fig. 3 for air-water system. It was observed that there is a decrease in gas holdup with an increase in particle diameter, which is mainly due to increasing the bubble breakage. The same trend is in agreement with the published literature results $^{\mathbf{2 0}}$. The influence of the sphericity of particle on gas holdup is shown in Fig. 4, from which it is observed that an increase of the sphericity of particle decreases the gas holdup and it is mainly due to decreasing the surface area per unit volume of particle which leads to less bubble

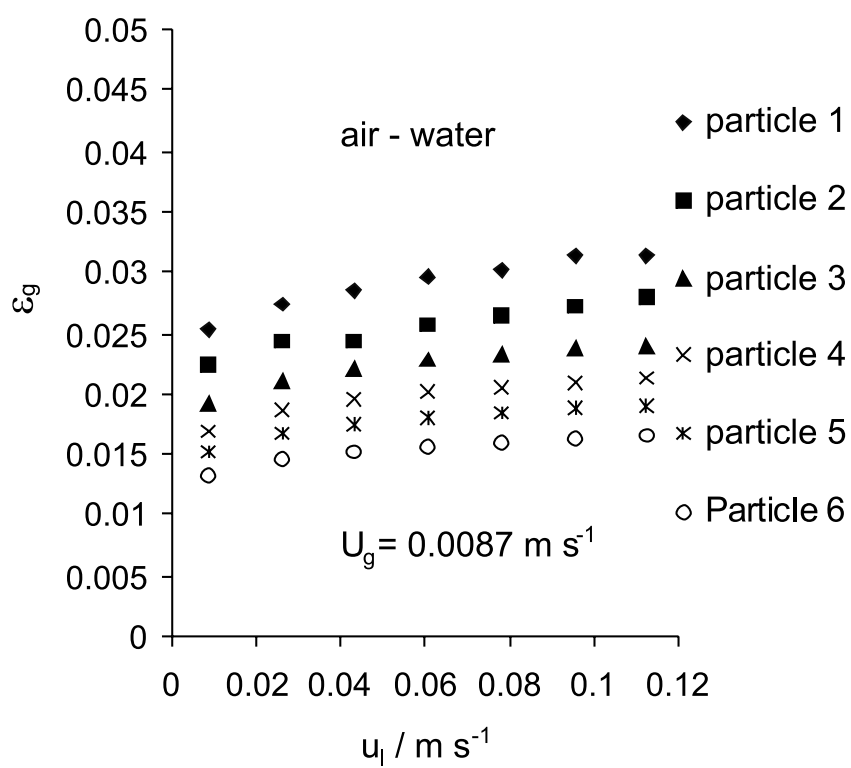

Figure 3. The effect of particle diameter on gas holdup

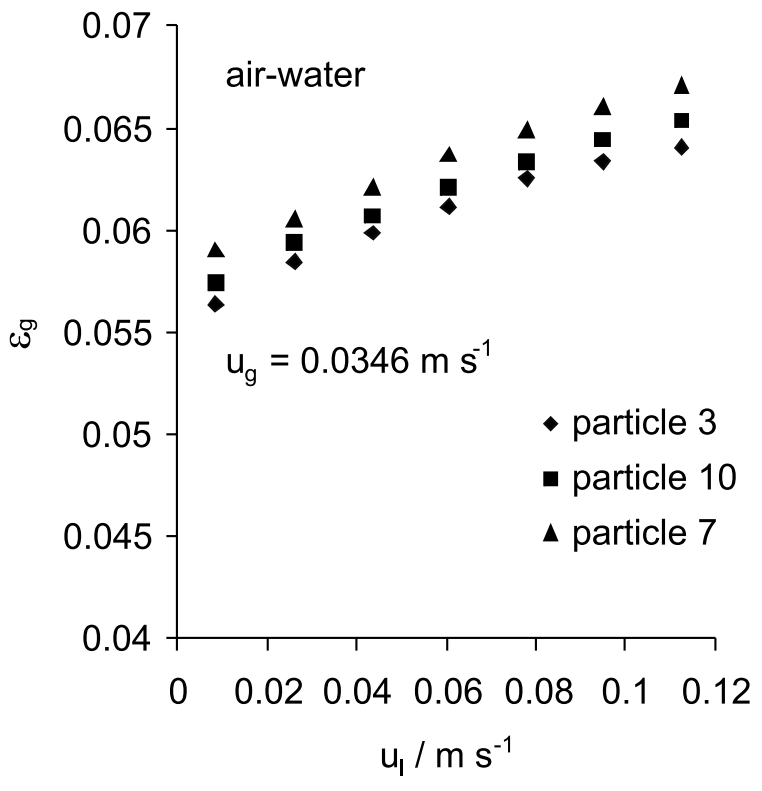

Figure 4. The effect of the sphericity of particle on gas holdup

breakage. The dependency of the gas holdup on liquid properties was analyzed using 11 different liquid systems. At constant liquid flow rate, gas holdup increases with increasing liquid viscosity, as shown in Figure 5. The same trend is also observed with an increasing flow consistency index (k) for non-Newtonian fluids (Fig. 6). Increasing the liquid viscosity/consistency index enhances the bubble breakages and hence the gas holdup increases ${ }^{\mathbf{1 8}}$.

The present experimental data and literature data $^{6}, 10,14,18,19,24,25$ were analyzed using the available literature correlations (Table 2). Begovich and Watson correlation 4 predicted good results with the data of Bloxom et al., ${ }^{10}$, Miura and Kawase ${ }^{\mathbf{1 8}}$ and Miura et al. ${ }^{\mathbf{1 9}}$ with the minimum AARD limits (less than 13\% AARD) but failed to comply with the rest of the data sets $\mathbf{6 , 1 4 , 2 4 , 2 5}$ (more than 25\% AARD). The reason could be that the effective physical properties of liquids and particle dimensions were not properly accounted for in the development of the correlation. The present experimental and literature data, when tested with the Parulekar and Shah ${ }^{\mathbf{1 1}}$

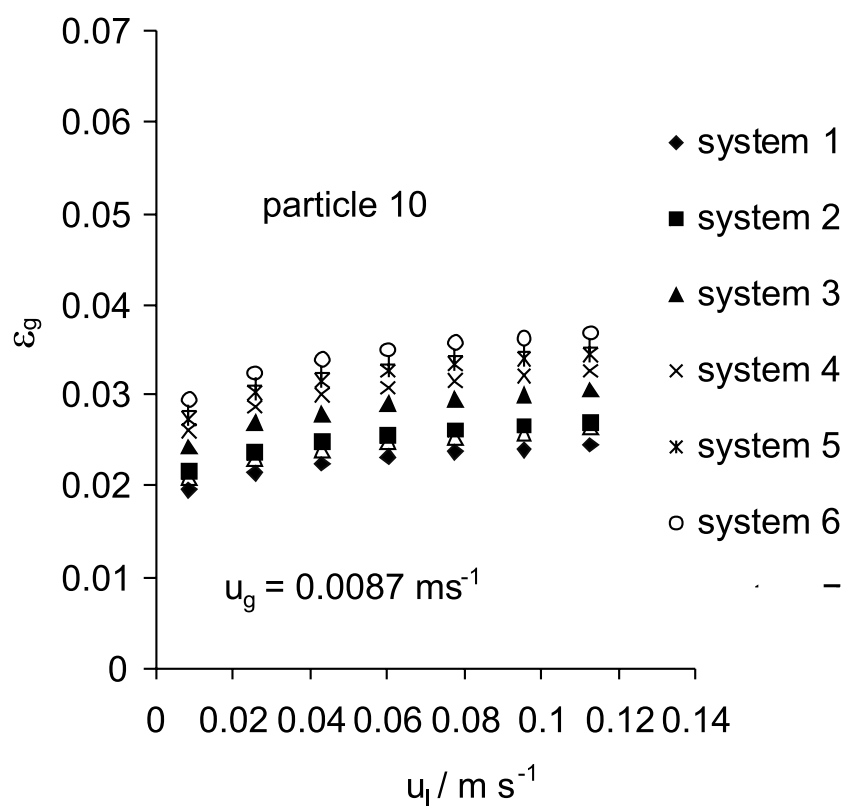

Figure 5. The effect of physical properties of liquids on gas holdup 
Table 2. A list of important literature correlations for gas holdup

\begin{tabular}{|c|c|c|c|}
\hline Author & Correlations & System & Range of variables \\
\hline $\begin{array}{l}\text { Begovich and } \\
\text { Watson } 4\end{array}$ & $\varepsilon_{g}=0.048\left(u_{g}\right)^{0.72} d_{p}^{0.168}(D)^{-0.125}$ & Air - water & $\begin{array}{l}d_{p}=0.0046-0.0062 \mathrm{~m} \\
\rho_{s}=1720-2440 \mathrm{~kg} / \mathrm{m}^{3} \\
u_{g}=0-0.173 \mathrm{~m} / \mathrm{s} \\
u_{l}=0-0.12 \mathrm{~m} / \mathrm{s} \\
D=0.0762 \& 0.152 \mathrm{~m}\end{array}$ \\
\hline $\begin{array}{l}\text { Parulekar and } \\
\text { Shah }{ }^{11}\end{array}$ & $\varepsilon_{g}=0.0866\left(\frac{1}{\sigma_{l}}\right)^{0.01} U_{g}^{0.5} D^{-0.08}$ & Hydrogen-oil & $\begin{array}{l}d_{p}=0.00005-0.000275 \mathrm{~m} \\
\rho_{s}=1300 \mathrm{~kg} / \mathrm{m}^{3} \\
\rho_{l}=900 \mathrm{~kg} / \mathrm{m}^{3} \\
u_{g}=0-0.030 \mathrm{~m} / \mathrm{s} \\
u_{l}=0.00075-0.003 \mathrm{~m} / \mathrm{s} \\
D=0.08-0.16 \mathrm{~m}\end{array}$ \\
\hline $\begin{array}{l}\text { Khang } \\
\text { et al. }{ }^{12}\end{array}$ & $\left(1-\varepsilon_{g}\right) u_{g}+\varepsilon_{g} u_{l}=\varepsilon_{g}\left(22.67 \varepsilon_{g}+10.44\right)$ & Air-kerosene & $\begin{array}{l}d_{p}=0.0011 \mathrm{~m} \\
\rho_{s}=1330 \mathrm{~kg} / \mathrm{m}^{3} \\
\rho_{\mathrm{l}}=810 \mathrm{~kg} / \mathrm{m}^{3} \\
\mu_{\mathrm{l}}=0.0014 \mathrm{~kg} / \mathrm{m} . \mathrm{s} \\
u_{g}=0-0.0022 \mathrm{~m} / \mathrm{s}\end{array}$ \\
\hline Jean and $\mathrm{Fan}^{13}$ & $\varepsilon_{g}=0.00164 u_{g}^{0.988}\left(-0.221 \times 10^{-5} u_{l}^{2}-0.564 u_{l}+28.281\right.$ & Air-water & $\begin{array}{l}d_{p}=0.00033-0.006 \mathrm{~m} \\
\rho_{s}=2200-22876 \mathrm{~kg} / \mathrm{m}^{3} \\
u_{\mathrm{l}}=0.0412-0.47 \mathrm{~m} / \mathrm{s} \\
u_{g}=0-0.1208 \mathrm{~m} / \mathrm{s}\end{array}$ \\
\hline $\mathrm{Yu}$ and $\mathrm{Kim}^{16}$ & $\varepsilon_{g}=3.697 d_{p}^{0.309} u_{l}^{-0.0222} u_{g}^{0.701}$ & Air- water & $\begin{array}{l}d_{p}=0.0004-0.006 \mathrm{~m} \\
\rho_{s}=2500 \mathrm{~kg} / \mathrm{m}^{3} \\
u_{g}=0.01-0.14 \mathrm{~m} / \mathrm{s} \\
u_{1}=0.006-0.01 \mathrm{~m} / \mathrm{s}\end{array}$ \\
\hline $\begin{array}{l}\text { Ramesh and } \\
\text { Murugesan }{ }^{26}\end{array}$ & $\begin{array}{l}\text { if } \mathrm{N}_{\mathrm{Re}, l} \leq 100 \\
\varepsilon_{g}=0.17\left(F r_{g}\right)^{0.33}\left(A r_{l}\right)^{0.125}\left(M o_{l}\right)^{0.05}\left(N_{\mathrm{Re}, l}\right)^{-0.065} \\
\text { if } \mathrm{N}_{\mathrm{Re}, l}>100 \\
\varepsilon_{g}=0.11\left(F r_{g}\right)^{0.35}\left(A r_{l}\right)^{0.11}\left(M o_{l}\right)^{0.075}\left(N_{\mathrm{Re}, l}\right)^{0.2}\end{array}$ & $\begin{array}{l}\text { Air-water or } \\
\text { MEA or } \\
\text { Glycerol }(25 \% \text {, } \\
55 \%)\end{array}$ & $\begin{array}{l}\mathrm{d}_{\mathrm{p}}=0.00411-0.0068 \mathrm{~m} \\
\rho_{\mathrm{s}}=2030-2480 \mathrm{~kg} / \mathrm{m}^{3} \\
\mathrm{u}_{\mathrm{g}}=0-0.13 \mathrm{~m} / \mathrm{s} \\
\mathrm{u}_{\mathrm{l}}=0-0.13 \mathrm{~m} / \mathrm{s} \\
\sigma_{\mathrm{l}}=0.049-.072 \mathrm{~N} / \mathrm{m} \\
\mu_{1}=0.0008-0.015 \mathrm{~kg} / \mathrm{m} . \mathrm{s} \\
\rho_{\mathrm{l}}=1000-1150 \mathrm{~kg} / \mathrm{m}^{3}\end{array}$ \\
\hline
\end{tabular}

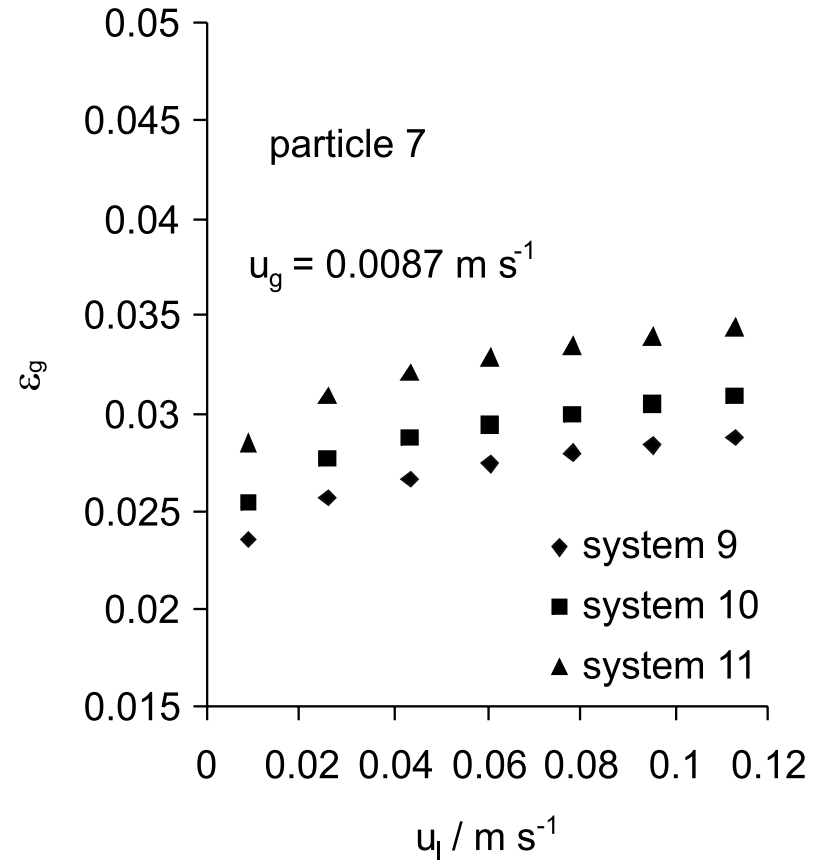

Figure 6. The effect of rheological properties of the nonNewtonian fluids on gas holdup

correlation for the prediction of gas holdup showed relatively high deviation ( $>70 \%$ AARD). This deviation may be attributed to the fact that even though the author had used hydrogen-oil systems, the individual physical properties of liquids and the solids were not properly taken into account for the development of the correlation. The present and the literature data, when tested with the Khang et al., ${ }^{\mathbf{1 2}}$ and Jean and Fan ${ }^{\mathbf{1 3}}$ correlation, gave high AARD (mote than $85 \%$ AARD). The authors studied only the influence of the gas and liquid flow rates on the gas holdup. Since the suggested correlation was developed using a restricted range of variables it gave high AARD when particles with other dimensions were considered. Yu and $\mathrm{Kim}^{\mathbf{1 6}}$ correlation predicted high deviation (more than $26 \%$ AARD) for Dhanuka and Stepanek ${ }^{6}$, SaberianBroudjenni et al. ${ }^{14}$, Oh and $\mathrm{Kim}^{24}$, and Nacef et al. ${ }^{25}$ data, compared to other available literature data of Bloxom et al. ${ }^{10}$, Miura and Kawase ${ }^{\mathbf{1 8}}$ and Miura et al. ${ }^{\mathbf{1 9}}$ and this was mainly due to the fact that the appropriate effects of physical properties of liquids, were not properly taken into account for the development of the correlation. Though Ramesh and Murugesan ${ }^{\mathbf{2 6}}$ had studied the effect of particle diameter, phase velocities and physical properties of the fluids on gas holdup, their correlation was restricted to Newtonian systems.

Graphical analysis of the present data (Fig. 2 - Fig. 6) shows that the variation of gas holdup can be attributed to the effect of all the above said variables. From the literature it is observed that most of the literature correlations were restricted to Newtonian liquid systems $\mathrm{4}^{\mathbf{4 1}-13,16,26}$ and hence those could not be used non-Newtonian fluids and hence in this study, the approach of dimensionless method was adopted for the establishment of the unified gas holdup 
Table 3. The details of the literature particles used for the gas holdup analysis

\begin{tabular}{|c|c|c|c|c|c|}
\hline Bed Characteristics & $\begin{array}{l}\text { Particle } \\
\text { Diameter, } \\
\mathrm{d}_{\mathrm{p}} / \mathrm{mm}\end{array}$ & $\begin{array}{l}\text { Particle } \\
\text { Density, } \\
\rho_{\mathrm{s}} / \mathrm{kg} \mathrm{m}^{-3} \\
\end{array}$ & $\begin{array}{l}\text { Particle } \\
\text { Sphericity, } \phi_{\mathrm{s}}\end{array}$ & $\begin{array}{l}\text { Column } \\
\text { Diameter, } \\
\mathrm{D} / \mathrm{mm} \\
\end{array}$ & Author \\
\hline Spheres & 4.08 & 2960 & 1 & 50 & \multirow[t]{2}{*}{ Dhanuka and Stepanek $^{6}$} \\
\hline Spheres & 5.86 & 2960 & 1 & 50 & \\
\hline Spheres & 4.62 & 2260 & 1 & 7.62 & Bloxom et al. $^{10}$ \\
\hline Spheres & 2.55 & 1380 & 1 & 52 & \multirow{3}{*}{$\begin{array}{l}\text { Saberian-Broudjenni et } \\
\text { al. }^{14}\end{array}$} \\
\hline Alumina Extrudates & 2 & 2160 & 0.78 & 52 & \\
\hline Alumina Extrudates & 2 & 1605 & 0.78 & 52 & \\
\hline Spheres & 3 & 2500 & 1 & 68 & \multirow{3}{*}{ Miura and Kawase $^{18}$} \\
\hline Spheres & 5 & 2500 & 1 & 68 & \\
\hline Spheres & 7 & 2500 & 1 & 68 & \\
\hline Spheres & 3 & 2500 & 1 & 68 & \multirow{2}{*}{ Miura et al. ${ }^{19}$} \\
\hline Spheres & 5 & 2500 & 1 & 68 & \\
\hline Spheres & 1.63 & 2500 & 1 & 15 & \multirow{3}{*}{ Oh and $\mathrm{Kim}^{24}$} \\
\hline Spheres & 2.92 & 2500 & 1 & 15 & \\
\hline Spheres & 7.85 & 2500 & 1 & 15 & \\
\hline Spheres & 1.2 & 2500 & 1 & 152 & \multirow{3}{*}{ Nacef et al. ${ }^{25}$} \\
\hline Spheres & 3.1 & 2500 & 1 & 152 & \\
\hline Spheres & 3.5 & 1245 & 1 & 152 & \\
\hline
\end{tabular}

Table 4. The details of the literature liquid systems used for the gas holdup analysis

\begin{tabular}{|c|c|c|c|c|c|}
\hline \multirow[b]{2}{*}{ Properties of fluids } & \multirow{2}{*}{$\begin{array}{l}\text { Liquid Density, } \\
\qquad \rho_{\mathrm{l}} / \mathrm{kg} \mathrm{m}^{-3}\end{array}$} & \multicolumn{2}{|c|}{ Liquid Viscosity, $\mu_{1}(\mathrm{~kg} / \mathrm{m} / \mathrm{s})$} & \multirow{2}{*}{$\begin{array}{l}\text { Liquid } \\
\text { Surface } \\
\text { Tension, } \\
\sigma_{\mathrm{l}} / \mathrm{Nm}^{-1}\end{array}$} & \multirow[b]{2}{*}{ Author } \\
\hline & & $\begin{array}{c}\mathrm{K} / \\
\mathrm{Kg} / \mathrm{m} / \mathrm{s}^{\mathrm{n}-2}\end{array}$ & $\mathrm{n}$ & & \\
\hline Water & 995 & 0.00085 & 1 & 0.0712 & Dhanuka and Stepanek $^{6}$ \\
\hline Glycerine Solution 1 & 1160 & 0.0038 & 1 & 0.064 & \multirow{3}{*}{ Bloxom et al. ${ }^{10}$} \\
\hline Glycerine Solution 2 & 1000 & 0.0009 & 1 & 0.07 & \\
\hline Glycerine Solution 3 & 1100 & 0.009 & 1 & 0.064 & \\
\hline Cyclohexane & 775 & 0.001 & 1 & 0.027 & \multirow{3}{*}{ Saberian et al. ${ }^{14}$} \\
\hline Tetrachloroethane & 1620 & 0.0009 & 1 & 0.032 & \\
\hline Kerosine & 780 & 0.0011 & 1 & 0.025 & \\
\hline Water & 997 & 0.0009 & 1 & 0.072 & \multirow{3}{*}{ Miura and Kawase ${ }^{18}$} \\
\hline$w=0.1 \% \mathrm{CMC}$ & 998 & 0.024 & 0.788 & 0.0728 & \\
\hline$w=0.2 \% \mathrm{CMC}$ & 999 & 0.169 & 0.625 & 0.073 & \\
\hline Water & 997 & 0.0009 & 1 & 0.072 & \multirow{4}{*}{ Miura et al. ${ }^{19}$} \\
\hline$w=0.05 \% \mathrm{CMC}$ & 997 & 0.0299 & 0.719 & 0.07 & \\
\hline$w=0.1 \% \mathrm{CMC}$ & 998 & 0.0648 & 0.687 & 0.07 & \\
\hline$w=0.1 \%$ Xanthan gum & 1000 & 0.0675 & 0.629 & 0.07 & \\
\hline Water & 1000 & 0.001 & 1 & 0.072 & Oh and $\mathrm{Kim}^{24}$ \\
\hline Water & 1000 & 0.001 & 1 & 0.072 & \multirow{2}{*}{ Nacef et al. ${ }^{25}$} \\
\hline$\varphi=1 \%$ Ethanol & 1000 & 0.001 & 1 & 0.067 & \\
\hline
\end{tabular}

correlation for both Newtonian and non-Newtonian liquids with a wide range of operating conditions (Tables $3-5$ ). The combined effects of the liquid properties of the Newtonian and the non-Newtonian fluids were accommodated using Modified Morton's number ${ }^{27}$, the effects of viscous force and gravity force were combined in terms of Froude number's of fluids, the ratio of the downward to upward force, the column geometry effects and particle sphericity were considered to develop the unified present correlation. Regression analysis of the available gas holdup data yielded the following constants and indices for the equation,

$\varepsilon_{g}=0.98\left(F r_{l}\right)^{0.0438}\left(F r_{g}\right)^{0.382}\left(M o_{l, M}\right)^{0.0265}\left(\rho_{s} / \rho_{l}\right)^{-0.529}\left(d_{p} / D\right)^{0.0339}\left(\phi_{s}\right)^{-0.0217}$

Statistical error analysis of the proposed correlation (Eqs. (1)) showed an AARD of $10.5 \%$ for gas holdup indicating a satisfactory representation of the available
Table 5. A range of variables used for the development of the proposed correlation

\begin{tabular}{|c|l|l|}
\hline S.No. & Variable & Range of variable used \\
\hline 1. & Superficial gas velocity $\left(\mathrm{u}_{\mathrm{g}}\right)$ & $0.00375-0.1375 \mathrm{~m} / \mathrm{s}$ \\
\hline 2. & Superficial liquid velocity $\left(\mathrm{u}_{\mathrm{I}}\right)$ & $0.008-0.2487 \mathrm{~m} / \mathrm{s}$ \\
\hline 3. & Particle diameter $\left(\mathrm{d}_{\mathrm{p}}\right)$ & $0.001-0.01366 \mathrm{~m}$ \\
\hline 4. & Sphericity of the particle $\left(\phi_{\mathrm{s}}\right)$ & $0.33-1.0$ \\
\hline 5. & Particle density $\left(\rho_{\mathrm{s}}\right)$ & $1245-2960 \mathrm{~kg} / \mathrm{m}^{3}$ \\
\hline 6. & Column diameter $(\mathrm{D})$ & $0.005-0.15 \mathrm{~m}$ \\
\hline 7. & Liquid density $\left(\left(\rho_{\mathrm{I}}\right)\right.$ & $995-1620 \mathrm{~kg} / \mathrm{m}^{3}$ \\
\hline 8. & Liquid viscosity $\left(\mu_{\mathrm{I}}\right)$ & $0.00085-0.032 \mathrm{~kg} / \mathrm{m} / \mathrm{s}$ \\
\hline 9. & Fluid consistency index $(\mathrm{k})$ & $0.00085-0.169 \mathrm{~kg} / \mathrm{m} / \mathrm{s}^{2-\mathrm{n}}$ \\
\hline 10. & Flow behaviour index $(\mathrm{n})$ & $0.625-1.0$ \\
\hline 11. & Liquid surface tension $\left(\sigma_{\mathrm{l}}\right)$ & $0.025-0.072 \mathrm{~N} \mathrm{~m}^{-1}$ \\
\hline
\end{tabular}

data for the air-Newtonian and the air-non Newtonian systems. The stastical analysis of the proposed and available literature correlations for the present and literature 
Table 6. Statistical comparison of gas holdup with the present and literature data

\begin{tabular}{|c|c|c|c|c|c|c|c|c|c|c|c|c|c|c|c|c|}
\hline \multirow{2}{*}{ Correlations } & \multicolumn{2}{|c|}{ Present data } & \multicolumn{2}{|c|}{$\begin{array}{l}\text { Dhanuka \& } \\
\text { Stepanek }^{6}\end{array}$} & \multicolumn{2}{|c|}{ Bloxom et al. ${ }^{10}$} & \multicolumn{2}{|c|}{$\begin{array}{l}\text { Saberian- } \\
\text { Broudjenni et } \\
\text { al. }^{14}\end{array}$} & \multicolumn{2}{|c|}{$\begin{array}{l}\text { Miura and } \\
\text { Kawase }^{18}\end{array}$} & \multicolumn{2}{|c|}{ Miura et a. ${ }^{19}$} & \multicolumn{2}{|c|}{ Oh and $\mathrm{Kim}^{24}$} & \multicolumn{2}{|c|}{ Nacef et al. ${ }^{25}$} \\
\hline & $\begin{array}{c}\text { AARD } \\
\%\end{array}$ & Bias & $\begin{array}{c}\text { AARD } \\
\%\end{array}$ & Bias & $\begin{array}{c}\text { AARD } \\
\%\end{array}$ & Bias & $\begin{array}{c}\text { AARD } \\
\%\end{array}$ & Bias & $\begin{array}{c}\text { AARD } \\
\%\end{array}$ & Bias & $\begin{array}{c}\text { AARD } \\
\%\end{array}$ & Bias & $\begin{array}{l}\text { AARD } \\
\%\end{array}$ & Bias & $\begin{array}{c}\text { AARD } \\
\%\end{array}$ & Bias \\
\hline $\begin{array}{l}\text { Begovich and } \\
\text { Watson } 4 \\
\end{array}$ & 19.5 & 1.06 & 24.1 & 0.81 & 13.55 & 0.89 & 42.4 & 1.7 & 8.9 & 1.05 & 9.02 & 0.92 & 78.6 & 0.64 & 27.6 & 1.3 \\
\hline $\begin{array}{l}\text { Parulekar and } \\
\text { Shah }{ }^{11}\end{array}$ & 129.4 & 0.54 & 127.1 & 0.45 & 85.5 & 0.61 & 17.2 & 0.93 & 43.3 & 0.7 & 65.1 & 0.61 & 159.3 & 0.4 & 87.4 & 0.56 \\
\hline Khang et al. ${ }^{12}$ & 306.1 & 0.32 & 799.8 & 0.12 & 185.8 & 0.35 & 44.6 & 0.7 & 131.5 & 0.44 & 149.7 & 0.4 & 392.6 & 0.21 & 177.9 & 0.38 \\
\hline Jean and Fan ${ }^{13}$ & 94.3 & 0.54 & 9.4 & 1.06 & 144.2 & 0.41 & 50.3 & 0.73 & 115.3 & 0.48 & 157.8 & 0.39 & 135.3 & 0.45 & 43.9 & 0.75 \\
\hline Yu and $\mathrm{Kim}^{16}$ & 25.8 & 1.1 & 24.6 & 1.3 & 5.95 & 1.01 & 55.5 & 2.27 & 17.5 & 1.2 & 6.5 & 1.06 & 48.7 & 0.89 & 30.5 & 1.4 \\
\hline $\begin{array}{l}\text { Ramesh and } \\
\text { Murugesan }{ }^{26} \\
N_{R e} \leq 100\end{array}$ & 26.4 & 1.30 & - & - & 10.66 & 1.1 & 47.5 & 1.92 & 29.3 & 1.42 & 15.5 & 1.1 & 22.2 & 1.28 & 35.9 & 1.60 \\
\hline \begin{tabular}{|l|} 
Ramesh and \\
Murugesan \\
$\mathrm{N}_{\mathrm{Re}}>100$ \\
\end{tabular} & 22.3 & 1.06 & 15.6 & 0.93 & 11.9 & 1.1 & 45.9 & 1.83 & 23.1 & 1.31 & 12.6 & 1.1 & 45.8 & 0.82 & 37.1 & 1.52 \\
\hline Present Eq (1) & 10.5 & 1.01 & 14.8 & 1.3 & 14.77 & 0.91 & 13.7 & 1.2 & 14.6 & 1.06 & 13.8 & 1.02 & 11.8 & 1.01 & 14.8 & 1.04 \\
\hline
\end{tabular}

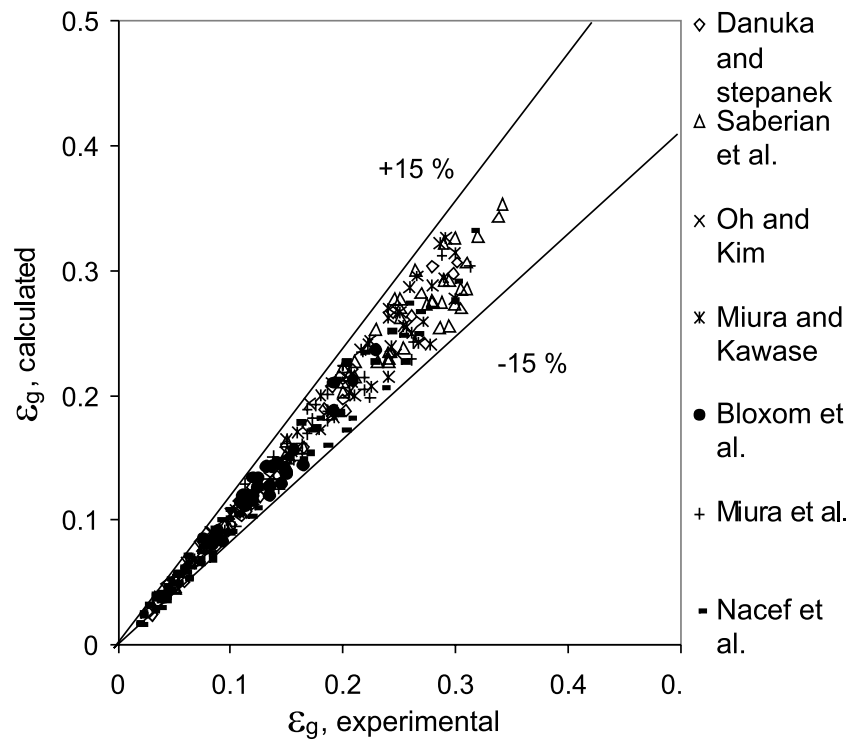

Figure 7. Comparison of the literature data vs. the calculated gas holdup using the present correlation

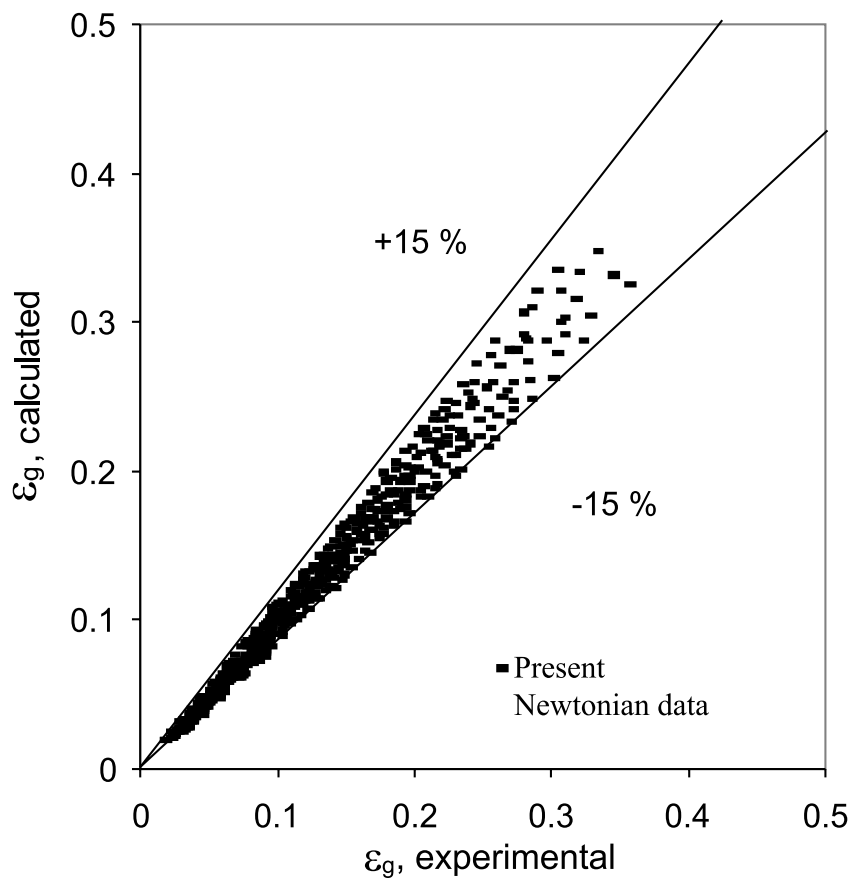

Figure 8. Comparison of the present experimental Newtonian data vs. calculated gas holdup using the present correlation

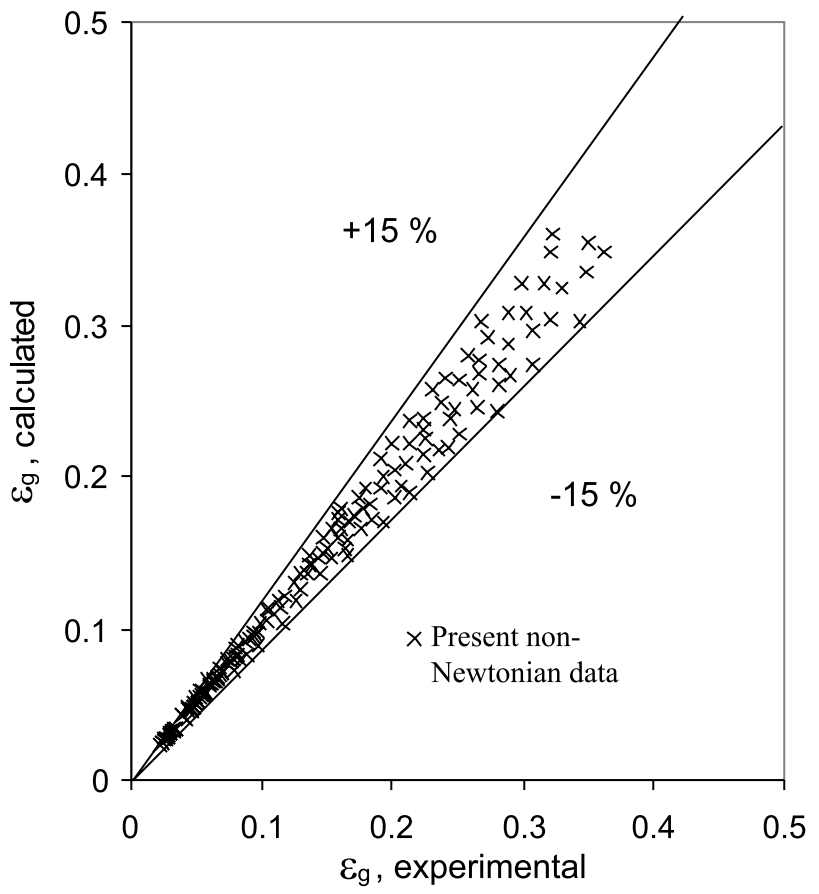

Figure 9. Comparison of the present experimental nonNewtonian data vs. calculated gas holdup using the present correlation

data were shown in the Table 6 . The validity of the present correlation has been tested with the available experimental literature gas holdup data and AARD found to be with in $15 \%$, which shows a satisfactory agreement (Figs. $7-9$ ).

\section{CONCLUSION}

In the present work, a careful analysis of the effect of the fundamental and operating variables on gas holdup has been studied in a three-phase fluidized bed using various Newtonian and non-Newtonian liquids. The experimental results indicate that the gas holdup increases with increased gas flow rate; viscosity of the liquid and flow consistency index whereas gas holdup decreases with increased particle diameter. The unified correlation for the estimation of gas holdup in a three-phase fluidized bed was developed using literature and the present data covering a wide range of variables. The statistical error analysis of the proposed correlation showed an AARD of $10.5 \%$ for gas holdup indicating a satisfactory represen- 
tation of the available data for the air-Newtonian and the air-non Newtonian systems. The validity of the present correlation has been tested with the available experimental literature gas holdup data and AARD found to be with in $15 \%$, which shows a satisfactory agreement and also the graphical analysis showed that the predictive ability of the present proposed correlation is good. Therefore, the proposed correlation can be confidently used for the estimation of the gas holdup, with the knowledge of the fundamental and operating variables.

$$
\begin{aligned}
& \text { Symbols used } \\
& \text { AARD }-\frac{1}{N} \sum_{i=1}^{N} \frac{\mid(\text { experimental }- \text { calculated }) \mid}{\text { experimental }},[-] \\
& \text { Bias }-\exp \frac{1}{N} \sum_{i=1}^{N} \ln \frac{\operatorname{experimental}}{\text { calculated }},[-] \\
& \text { D - column diameter, [m] } \\
& d_{p} \quad-\text { particle diameter, [m] } \\
& \mathrm{Fr}_{\mathrm{g}} \quad \text { - Froude number of gas, } \mathrm{u}_{2}{ }^{\mathrm{g}} \mathrm{g}^{-1} \mathrm{~d}_{\mathrm{p}}{ }^{-1} \\
& \mathrm{Fr}_{l} \quad \text { - Froude number of liquid, } \mathrm{u}_{1}{ }^{\mathrm{g}} \mathrm{g}^{-1} \mathrm{~d}_{\mathrm{p}}{ }^{-1} \\
& g \quad-\text { acceleration due to gravity, }\left[\mathrm{m} \mathrm{s}^{-2}\right. \text { ] } \\
& K \quad-\text { flow consistency index, }\left[\mathrm{kg} \mathrm{m}^{-1} \mathrm{~s}^{\mathrm{n}-2}\right] \\
& \mathrm{L} \text { - length of the non- spherical particles, [m] } \\
& M o_{l, M} \text { - modified Morton number of liquid, } \\
& d_{p}^{4(1-n)} u_{l}^{4(n-1)} g k^{4} \sigma_{l}^{-3} \rho_{l}^{-1},[-] \\
& N \quad \text { - number of data points, [-] } \\
& \mathrm{n} \text { - fluid behavior index, [-] } \\
& u_{g} \quad-\text { superficial gas velocity, [m }{ }^{\mathrm{s}-1} \text { ] } \\
& u_{l} \quad-\text { superficial liquid velocity, }\left[\mathrm{m} \mathrm{s}^{-1}\right] \\
& \text { w - mass fraction, } \%
\end{aligned}
$$

\section{Greek letters}

$\begin{array}{ll}\rho_{l} & - \text { liquid density, }\left[\mathrm{kg} \mathrm{m}^{-3}\right] \\ \sigma_{l} & - \text { liquid surface tension, }\left[\mathrm{N} \mathrm{m}^{-1}\right] \\ \mu_{l} & - \text { liquid viscosity, }\left[\mathrm{kg} \mathrm{m}^{-1} \mathrm{~s}^{-1}\right] \\ \rho_{s} & \text { - particle density, }\left[\mathrm{kg} \mathrm{m}^{-3}\right] \\ \varepsilon_{g} & - \text { gas holdup, }[-] \\ \phi_{s} & - \text { sphericity of the particle, }[-] \\ \rho_{g} & - \text { gas density, }\left[\mathrm{kg} \mathrm{m}^{-3}\right] \\ \mu_{l} & - \text { gas viscosity, }\left[\mathrm{kg} \mathrm{m}^{-1} \mathrm{~s}^{-1}\right] \\ \varphi & - \text { volume fraction, } \%\end{array}$

\section{Abbreviations}

$\begin{array}{ll}\text { AARD } & - \text { absolute average relative deviation } \\ \text { CMC } & - \text { carboxy methyl cellulose } \\ \text { MEA } & - \text { mono ethanol amine }\end{array}$

\section{LITERATURE CITED}

1. Jena, H. M., Roy, G. K. \& Meikap, B. C. (2008). Hydrodynamics of a gas-liquid-solid fluidized bed with hollow cylindrical particles. Chem. Eng. and Process.: Process Intensification, 48, 279 - 287. http://dx.doi.org/10.1016/j.cep.2008.04.003.

2. Jena, H. M., Sahoo, B. K., Roy, G. K. \& Meikap, B. C. (2008). Characterization of hydrodynamic properties of a gas-liquid-solid three-phase fluidized bed with regular shape spherical glass bead particles, Chem. Eng. J., 145, 50 - 56, http://dx.doi.org/10.1016/j.cej.2008.03.002.

3. Sivakumar, V. \& Senthilkumar, K. (2010). Prediction of minimum fluidization velocity in two-phase and three-phase fluidized beds: Air/Newtonian and non-Newtonian liquids, Int. J. Chem. Reactor Eng., 8, article A91,1-18. http:// www.bepress.com/ijcre/vol8/A91.
4. Begovich, J. M. \& Watson, J. S. (1978). Hydrodynamic characteristics of three-phase fluidized beds. Fluidization, 190. h t t p : / / w w w . os t i.gov/e n e r g y c i tation s/ product.biblio.jsp?osti_id $=7208327$.

5. Fan, L. S. (1989). Gas-liquid-solid fluidization engineering, Butterworth series in chemical engineering, Butterworth, Boston. DOI:10.1016/0017-9310(90)90132-E.

6. Dhanuka, U. R. \& Stepanek, J. B. (1978). Gas and liquid holdup and pressure drop measurements in a three phase fluidized bed. Fluidization, 179.

7. Min, J., Drake, J. B., Heindel, T. J. \& Fox, R. O. (2009). Experimental validation of CFD simulations of a lab-scale fluidized-bed reactor with and without side-gas injection, Particle Technology and Fluidization, 56, 1434. DOI: 10.1002/ aic.12077.

8. Ramesh, K. V., Raju, G. M. J., Sarma, G. V. S. \& Bhaskara Sarma, C. (2009). Effect of internal on phase holdups of a three-phase fluidized bed. Chem. Eng. J. 145, 393. DOI:10.1016/ j.cej.2008.08.023.

9. Jena, H. M., Roy, G. K. \& Mahabatra, S. S. (2010). Determination of optimum gas holdup conditions in a threephase fluidized bed by genetic algorithm, Computers and chemical Eng. 34, 476. DOI: 10.1016/j.compchemeng.2009.07.03.

10. Bloxom, V. R., Costa, J., Herranz, J., Mac William, G. L., \& Roth, S. R. (1975). Determination and correlation of hydrodynamic variables in a three-phase fluidized bed. MIT report N219, Oak Ridge National laboratory, Oak Ridge, TN,. http://www.fischer-tropsch.org/DOE/DOE_reports/MIT/219/ ornlmit219_toc.htm

11. Parulekar, S. J. \& Shah, Y. T. (1980). Steady state behavior of Gas-Liquid-Solid fluidized bed reactors. Chem. Eng. J. 20, 21 - 33. DOI: 10.1016/0300-9467(80)85003-9.

12. Khang, S. J., Schwartz, J. G., Buttke, R. D. (1983). A practical wake model for estimating bed expansion and holdup in three phase fluidized bed systems. Fluidization and fluid particle systems, AIChE Symp. Series, 79, 47.

13. Jean, R. H., Fan, L. S. (1987). On the particle terminal velocity in a gas liquid medium with liquid as the continuous phase. Can. J. Chem. Eng. 65, 881. DOI: 10.1002/ cjce. 5450650601 .

14. Saberian-Broudjenni, M. N., Wild, G., Charpentier, J. C., Fortin, Y., Euzen, J. P., \& Patoux, R. (1987). Contribution to hydrodynamic study of gas-liquid-solid fluidization bed reactors. Int. Chem. Eng. 27, 423. DOI: 10.1002/ cjce. 5450630405 .

15. Fuentes, M., Mussati, M. C., Scenna, N. J. \& Aguirre, P. A. (2009). Global modeling and simulation of a threephase fluidized bed bioreactor, Computer and Chemical Eng., 33, 359. DOI:10.1016/j.compchemeng.2008.10.001

16. Yu, K. \& Kim, S. D. (1988). Bubble Characteristics in the radial direction of three phase fluidized beds. AIChE J. 34, 2069. DOI:10.1002/aic.690341217.

17. Masud Hossain, Sk. \& Das, M. (2010) Anaerobic biogas generation from sugar industry wastewaters in three-phase fluidized-bed bioreactor, Can. J. Chem. Eng. DOI:10.1002/ cjce. 20347.

18. Miura, H. \& Kawase, Y. (1997). Hydrodynamics and mass transfer in three phase fluidized beds with nonNewtonian fluids. Chem. Eng. Sci. 52, 21 - 22, 4095-4104. DOI: 10.1016/S0009-2509(97)00251-0.

19. Miura, H., Takahashi, T. \& Kawase, Y. (2001). Effect of pseudo plastic behavior of liquid in co-current three phase fluidized beds on bed expansion. Chem. Eng. Sci. 56, 6047. DOI: 10.1016/S0009-2509(01)00219-6.

20. Chhbra, R. P., Comiti, J., \& Machac, I. (2001). Flow of non-Newtonian fluids in fixed and fluidised beds. Chem. Eng. Sci. 56, 1. DOI: 10.1016/S0009-2509(00)00207-4.

21. Van der Lee, L., Chandrasekaran, B., Hulme,I. \& Kantzas, A. (2005). A non-invasive hydrodynamic study of 
gas-solid fluidized bed of linear low density polyethylene. Can.

J. Chem. Eng., 83, 119. DOI: 10.1002/cjce.5450830120.

22. Sivakumar,V., Senthilkumar, K. \& Akilamudhan, P. (2008) Prediction of liquid and solid holdup in three-phase fluidized bed: Air-Newtonian and non-Newtonian liquids. Biochem.

Eng. Q. 22 (4), 401 - 410. http://hrcak.srce.hr/ index.php?show $=$ clanak\&id_clanak_jezik $=48524$.

23. Safoniuk, M., Grace, J. R., Hackman, L. \& McKnight, C. A. (2002). Gas hold-up in a three-phase fluidized bed. AIChE J. 48, 1581 - 1587. DOI: 10.1002/aic.690480720

24. Oh, J. S. \& Kim, S.D. (1980). Phase holdup characteristics of three phase fluidized beds. J. Korean Ins. Chem. Ers. 18, 375. www.cheric.org/PDF/HHKH/HK18/HK18-5-03 75.

25. Nacef, S., Wild, G., Laurent, A. \& Kim, S. D. (1992). Scale effects in gas-liquid-solid fluidization. Int. Chem. Eng. 32, 51. DOI: 0020-6318/3216-0051/S05.00.

26. Ramesh, K. \& Murugesan, T. (2002). Minimum fluidization velocity and gas holdup in gas-liquid solid fluidized bed reactors. J. Chem. Tech. Biotech. 77, 129. DOI:10.1002/jctb.533.

27. Clift, R., Grace, J.R. \& Weber M.R. (1979). Bubbles Drops and Particles, Academic Press New York. http:// wapedia.mobi/en/Morton_number. 